\title{
Hubungan Pengkonsumsian Buah Pepaya Hijau Terhadap Kelancaran Produksi Asi Pada Ibu Menyusui di Desa Tanjung Alam Tahun 2020
}

\author{
Nani Jahriani* \\ *Sekolah Tinggi Ilmu Kesehatan AS SYIFA KISARAN \\ Email : jahriani@yahoo.com
}

\begin{abstract}
ABSTRAK
ASI adalah hadiah terindah dari ibu kepada bayi yang disekresikan oleh kedua belah kelenjar payudara ibu berupa makanan alamiah atau susu terbaik bernutrisi dan berenergi tinggi yang mudah dicerna dan mengandung komposisi nutrisi yang seimbang dan sempurna untuk tumbuh kembang bayi yang tersedia setiap saat, siap disajikan dalam suhu kamar dan bebas dari kontaminasi. Provinsi Sumatera Utara sendiri memiliki cakupan persentase anak yang diberi ASI eksklusif dari tahun 2010-2015 cenderung menurun signifikan, cakupan ASI eksklusif pada tahun 2010 sebesar 55,1\% sedangkan pada tahun 2015 mengalami penurunan dibandingkan tahun 2014 yaitu sekitar 62.777 (33\%) dari 189.985 jiwa. Jenis Penelitian ini adalah penelitian pre-eksperimental designs. Bentuk penelitian pre-eksperimental ini dilaksanakan dengan rancangan one-group pretest-posttest design yang mana pada desain ini terdapat pretest (sebelum diberi perlakuan). Populasi dalam penelitian ini adalah seluruh ibu menyusui yang memiliki masalah pada produksi ASI yang tidak lancar sebanyak 10 orang. Teknik pengambilan sampel yang digunakan adalah kuota sampling sampel sebanyak 10 orang. Data diambil dengan lembar check list dan diolah dengan univariat dan bivariat dengan uji Chi-Square. Hasil penelitian ini pretest mayoritas responden sebelum mengkonsumsi buah pepaya hijau mengalami ketidak lancaran ASI sebanyak 10 orang (100\%). Sedangkan dari hasil posttest mayoritas responden setelah mengkonsumsi buah pepaya hijau yang ASI nya lancar sebanyak 10 orang (10\%). Hasil dari Uji Chi-Square, di mana nilai $\mathrm{P}$ value adalah $0,038<0,05$. Hal ini memiliki arti bahwa hipotesis yang masuk $\left(\mathrm{H}_{0}\right)$ ditolak dan Ha diterima dimana memiliki arti bahwa ada hubungan antara pengkonsumsian buah pepaya hijau dengan kelancaran produksi asi pada ibu menyusui di desa tanjung alam tahun 2020. Kesimpulan penelitian ada hubungan pengkonsumsian buah pepaya hijau terhadap kelancaran produksi ASI pada ibu menyusui di Desa Tanjung Alam Tahun 2020. Disarankan kepada kepala desa untuk menganjurkan kepada petugas kesehatan untuk memberikan penyuluhan tentang kelancaran produksi ASI pada ibu menyusui.
\end{abstract}

Kata kunci: Buah Pepaya Hijau, Produksi ASI 


\section{PENDAHULUAN}

ASI adalah hadiah terindah dari ibu kepada bayi yang disekresikan oleh kedua belah kelenjar payudara ibu berupa makanan alamiah atau susu terbaik bernutrisi dan berenergi tinggi yang mudah dicerna dan mengandung komposisi nutrisi yang seimbang dan sempurna untuk tumbuh kembang bayi yang tersedia setiap saat, siap disajikan dalam suhu kamar dan bebas dari kontaminasi (Rizki, 2019).

Menurut Riskesdas 2013, proses mulai menyusui terbanyak terjadi pada 1-6 jam setelah kelahiran $(35,2 \%)$ dan kurang dari 1 jam/inisiasi menyusui dini sebesar $(34,5 \%)$, sedangkan proses mulai menyusui terendah terjadi pada 7-23 jam setelah kelahiran yaitu sebesar $(3,7 \%)$. Cakupan pemberian ASI eksklusif pada bayi umur 0-6 bulan menurut Provinsi tahun 2015 dimana persentase Nusa Tenggara Barat yaitu 74,1\%, Nusa Tenggara Selatan 77,0\%, Bengkulu 75,0\%, Sumatera Barat 74,1\%, dan persentase yang terendah adalah di Sulawesi Utara 26,3\%. Pemberian ASI eksklusif yang masih rendah dapat menimbulkan masalah gizi pada balita. Upaya untuk menanggulanginya antara lain dengan meningkatkan dan melancarkan kualitas ASI (Desi, Sherly, 2018).

Provinsi Sumatera Utara sendiri memiliki cakupan persentase anak yang diberi ASI eksklusif dari tahun 2010-2015 cenderung menurun signifikan, cakupan ASI eksklusif pada tahun 2010 sebesar 55,1\% meningkat menjadi 56,6\% pada tahun 2011 dan pada tahun 2012 cakupan menurun kembali menjadi 32,2\%, pada tahun 2013 meningkat menjadi 41,3\%, selanjutnya pada tahun 2014 mengalami penurunan menjadi 37,6\% sedangkan pada tahun 2015 mengalami penurunan dibandingkan tahun 2014 yaitu sekitar 62.777 (33\%) dari 189.985 jiwa (Irwansyah, 2017). Pada pemberian ASI sering terjadi kendala-kendala baik dari ibu maupun bayi. Pada ibu menyusui seperti produksi ASI yang kurang dikarenakan ibu kurang memahami tata laksana laktasi yang benar, ibu ingin menyusui kembali setelah bayi diberi susu formula (relaktasi), bayi terlanjur mendapatkan prelakteal feeding (pemberian air gula/dekstrosa, susu formula pada hari-hari pertama kelahiran), kelainan ibu seperti puting ibu lecet, puting ibu luka, payudara bengkak dan ibu bekerja sedangkan pada bayi sering terjadi kendala seperti bayi sakit dan abnormalitas bayi (Istiqomah dkk, 2015). Selain itu pasca melahirkan seorang ibu dianjurkan untuk sering melakukan Yoga. Hal ini dapat mempengaruhi kelancaran ASI pada ibu yang baru melahirkan (Anggriani, 2020).

Profil Dinas Kesehatan Kabupaten Asahan merupakan salah satu Kabupaten yang berada di Sumatera Utara. Cakupan anak yang diberi ASI eksklusif dari tahun 2010-2015 sangat fluktuatif karena cakupan ASI eksklusif pada tahun 2010 sebesar 25,57\% meningkat menjadi 28,79\%, pada tahun 2011 dan pada tahun 2012 cakupan menurun kembali menjadi 28,45\%, pada tahun 2013 menurun menjadi 12\%, selanjutnya pada tahun 2014 terjadi sedikit peningkatan menjadi $15,45 \%$ sedangkan pada tahun 2015 juga terjadi sedikit peningkatan menjadi 15,62\% (2.305 jiwa) dari jumlah anak yang ada 14.761 anak (Irwansyah, 2017).

Pepaya sebagai salah satu buah yang mengandung Laktagogum merupakan buah tropis yang dikenal dengan sebutan Caricapapaya. Laktagogum adalah obat yang dapat meningkatkan atau memperlancar pengeluaran air susu. Kandungan lain yang terdapat di buah pepaya seperti pati $(43,28 \%)$, gula $(15,15 \%)$, protein $(13,63 \%)$, lemak $(1,29 \%)$, kelembaban $(10,65 \%)$, serat $(1,88 \%)$. Hal ini menunjukkan bahwa buah pepaya muda kaya nutrisi dan menjelaskan bahwa pepaya bermanfaat dalam banyak pengobatan (Desi, Sherly, 2018). Faktor lain yang mempengaruhi kelancaran ASI adalah faktor keseimbangan tubuh, oleh karena itu agar ASI tetap lancer harus tetap melakukan kegiatan olah raga agar keseimbangan tubuh tetap terjaga (Sulaiman; Anggriani, 2018).

Berdasarkan hasil survey awal yang dilakukan peneliti di Desa Tanjung Alam Dusun III, Peneliti melakukan wawancara langsung kepada Bidan Desa di Desa Tanjung Alam Dusun III bahwa jumlah ibu nifas sebanyak 25 orang. Ada 15 orang ibu nifas yang ASI nya lancar dan 10 orang ibu nifas yang ASI nya tidak lancar. 
Merujuk dari data diatas maka peneliti tertarik untuk mengambil judul penelitian tentang "Hubungan Pengkonsumsian Buah Pepaya Hijau Terhadap Kelancaran Produksi ASI Pada Ibu Menyusui Di Desa Tanjung Alam Tahun 2020".

\section{METODE PENELITIAN}

Jenis Penelitian ini adalah penelitian pre-eksperimental designs, desain ini belum merupakan eksperimen yang sungguh-sungguh karena masih terdapat variabel luar yang ikut berpengaruh terhadap terbentuknya variabel dependen. Jadi hasil eksperimen yang merupakan variabel dependen itu bukan semata-mata dipengaruhi oleh variabel independen. Bentuk penelitian pre-eksperimental ini dilaksanakan dengan rancangan one-group pretest-posttest design yang mana pada desain ini terdapat pretest (sebelum diberi perlakuan). Dengan demikian hasil perlakuan dapat diketahui lebih akurat, karena dapat membandingkan dengan keadaan sebelum diberi perlakuan.

\section{Metode Analisis Data}

Analisis univariat bertujuan untuk menjelaskaan atau mendeskripsikan karateristik setiap variabel penelitian. Bentuk analisis univariat Analisa univariat tergantung dari jenis datanya. Untuk data numerik digunakan nilai man atau rata-rata, median dan standardevsiasi. Pada umumnya dalam analisis ini hanya menghasilkan distribusi frekuensi dan presentase dari tiap variabel.

Analisis data dalam penelitian ini menggunakan analisa bivariat. Analisa bivariat dilakukan terhadap dua variabel yang diduga berhubungan atau berkolerasi. Penelitian ini menggunakan uji Chi-Square dengan tingkat kemaknaan $\mathrm{p}<0,05$.

\section{HASIL DAN PEMBAHASAN}

\section{Riwayat Ibu Menyusui}

Identitas responden yang terdiri atas usia. Berdasarkan tabel tersebut diketahui bahwa range usia responden yaitu 23-36 tahun. Responden yang berusia 23-30 tahun berjumlah 7 responden (70\%), responden yang berusia 31-35 tahun berjumlah 2 responden (20\%), sedangkan responden yang berusia $>35$ tahun berjumlah 1 responden $(10 \%)$. Jumlah seluruh responden 10 orang dan semuanya mengalami ketidak lancaran ASI. Berdasarkan hasil penelitian di lapangan, mayoritas ibu menyusui yang ASI nya tidak lancar berusia 23-30 tahun.

Pendidikan terakhir responden dibagi menjadi 2 yaitu SMP dan SMA. Jumlah responden yang memiliki latar belakang pendidikan SMP berjumlah 1 orang (10\%) dan responden yang memiliki latar belakang pendidikan SMA berjumlah 9 responden. Berdasarkan hasil penelitian di lapangan, mayoritas Pendidikan terakhir ibu menyusui yaitu SMA.

Pekerjaan responden adalah ibu rumah tangga yaitu sebanyak 10 orang (100\%). Berdasarkan hasil penelitian di lapangan, mayoritas pekerjaaan ibu menyusui adalah ibu rumah tangga.

Berdasarkan usia, pendidikan terakhir, dan pekerjaan tidak berpengaruh terhadap produksi ASI, di karenakan hanya sebagai pendukung identitas responden. Jadi tidak terdapat kesenjangan antara teori dan penelitian yang dilakukan di lapangan. 


\section{Hubungan Pengkonsumsian Buah Pepaya Hijau Terhadap Kelancaran Produksi ASI Pada Ibu Menyusui}

Sebelum mengkonsumsi buah pepaya hijau, responden berusia 23-30 tahun yang ASI nya tidak lancar sebanyak 7 orang (70\%), responden berusia 31-35 tahun yang ASI nya tidak lancar sebanyak 2 orang (20\%), responden berusia > 35 tahun yang ASI nya tidak lancar sebanyak 1 orang $(10 \%)$. Sedangkan setelah mengkonsumsi buah pepaya hijau, responden berusia 23-30 tahun yang ASI nya lancar sebanyak 7 orang (70\%), responden berusia 31-35 tahun yang ASI nya lancar sebanyak 2 orang (20\%), dan responden berusia $>35$ tahun yang ASI nya lancar sebanyak 1 orang (10\%). Maka hasil dari penelitian di lapangan, mayoritas responden mengalami perubahan pada produksi ASI yang tidak lancar menjadi lancar setelah di berikan pengkonsumsian buah pepaya hijau.

Hasil dari Uji Chi-Square, di mana nilai $\mathrm{P}$ value adalah $0,038<0,05$. Hal ini memiliki arti bahwa hipotesis yang masuk $\left(\mathrm{H}_{0}\right)$ ditolak dan Ha diterima, dimana memiliki arti bahwa ada hubungan antara pengkonsumsian buah pepaya hijau dengan kelancaran produksi asi pada ibu menyusui di desa tanjung alam tahun 2020 .

Pepaya sebagai salah satu buah yang mengandung Laktagogum merupakan buah tropis yang dikenal dengan sebutan Caricapapaya. Buah pepaya juga merupakan salah satu jenis buah yang memiliki kandungan nutrisi tinggi dan kaya akan manfaat bagi kesehatan. Laktagogum merupakan obat yang dapat meningkatkan atau memperlancar pengeluaran air susu. Laktagogum sintetis tidak banyak dikenal dan relatif mahal. Upaya dalam peningkatan produksi ASI bisa dilakukan dengan cara melakukan perawatan payudara sejak dini dan rutin, memperbaiki teknik menyusui, atau dengan mengkonsumsi makanan yang dapat mempengaruhi produksi ASI. Beberapa diantaranya berkhasiat sebagai laktagogum seperti tanaman katuk, lampes, adas manis, bayam duri, bidara upas, blustru, sayap ayam, jinten hitam pahit, kelor, nangka, patikan kebo, pulai, temulawak, turi, dan buah pepaya muda (Istiqomah dkk, 2015).

Tanaman pepaya merupakan tanaman yang banyak digunakan oleh masyarakat sejak dulu. Senyawa aktif yang terkandung di dalamnya yaitu enzim papain, karotenoid, alkaloid, flavonoid, monoterpenoid, mineral, vitamin, glukosinolat, dan karposida vitamin C, A, B, E, serta mineral. Dikatakan juga bahwa pepaya memiliki efek gastroprotektif, antibakterial, laksatif, dan laktagogum yang khasiatnya telah terbukti secara ilmiah dari buah pepaya. Kandungan laktagogum dalam pepaya dapat menjadi salah satu cara untuk meningkatkan laju sekresi dan produksi ASI dan menjadi strategi untuk menanggulangi gagalnya pemberian ASI eksklusif yang disebabkan oleh produksi ASI yang rendah. Mekanisme kerja laktagogum dalam membantu meningkatkan laju sekresi dan produksi ASI adalah dengan secara langsung merangsang aktivitas protoplasma pada sel-sel sekretoris kelenjar susu dan ujung saraf sekretoris dalam kelenjar susu yang mengakibatkan sekresi air susu meningkat, atau merangsang hormon prolaktin yang merupakan hormon laktagonik terhadap mamae pada selsel epitelium alveolar yang akan merangsang laktasi (Muhartono dkk, 2018).

Buah pepaya juga merupakan salah satu jenis buah yang memiliki kandungan enzim-

enzim, vitamin C, A, B dan E, serta mineral. Kandungan kimia buah pepaya muda mengandung polifenol, dan steroid. Peningkatan produksi ASI dipengaruhi oleh adanya polifenol dan steroid yang mempengaruhi reflek prolaktin untuk merangsang alveolus yang akan membuat ASI mengalir lebih deras dibandingkan dengan sebelum mengkonsumsi buah pepaya (Desi, Sherly, 2018).

Berdasarkan teori tentang buah pepaya hijau serta kandungan-kandungan yang ada pada buah pepaya hijau memiliki hubungan yang signifikan dengan kelancaran produksi ASI sehingga tidak terdapat kesenjangan antara teori dengan penelitian yang dilakukan di lapangan. 


\section{KESIMPULAN}

Dari hasil penelitian yang berjudul Hubungan Pengkonsumsian Buah Pepaya Hijau Terhadap Kelancaran Produksi ASI Pada Ibu Menyusui Di Desa Tanjung Alam Tahun 2020. Dengan responden sebanyak 10 orang peneliti menggunakan lembar check list yang berisi sebanyak 10 pertanyaan. Kemudian hasil di sajikan dalam bentuk tabel distribusi frekuensi dan analisis data menggunakan uji Chi-Square. Maka dapat disimpulkan hasil penelitian sebagai berikut :

a. Sebelum Mengkonsumsi Buah Pepaya hijau

Berdasarkan hasil penelitian menunjukkan kelancaran ASI sebelum mengkonsumsi buah pepaya hijau. Mayoritas responden mengalami ketidak lancaran ASI sebanyak 10 orang $(100 \%)$.

b. Setelah Mengkonsumsi Buah Pepaya Hijau

Berdasarkan hasil penelitian menunjukkan kelancaran produksi ASI responden setelah mengkonsumsi buah pepaya hijau. Mayoritas responden yang ASI nya lancar sebanyak 10 orang $(10 \%)$.

c. Hubungan Pengkonsumsian Buah Pepaya Hijau Terhadap Kelancaran Produksi ASI Pada Ibu Menyusui

Hasil dari Uji Chi-Square, di mana nilai $\mathrm{P}$ value adalah $0,038<0,05$. Hal ini memiliki arti bahwa hipotesis yang masuk $\left(\mathrm{H}_{0}\right)$ ditolak dan Ha diterima dimana memiliki arti bahwa ada hubungan antara pengkonsumsian buah pepaya hijau dengan kelancaran produksi asi pada ibu menyusui.

\section{DAFTAR PUSTAKA}

Anik Maryunani. 2018. Inisiasi Menyusu Dini, ASI Eksklusif dan Manajemen Laktasi. TIM: Jakarta.

Atika, Eni. 2019. Kapita Seleksi ASI \& Menyusui. Nuha Medika: Yogyakarta. Anggriani. 2020. Yoga Efektif Menurunkan Syaraf Kejepit. CV.AA Rizky. Serang-Banten Bambang Cahyono. 2017. Pepaya Budi Daya Intensif Pertanian Organik dan Anorganik. PT. SEWU ( Srikandi Empat Widya Utama): Bandung.

Desi, Sherly. 2018. Peningkatan Produksi ASI dengan Konsumsi Buah Pepaya. Jurnal Kesehatan Prima Nusantara Bukittinggi: 9(1).1-4.

Indra Iswari. 2018. Gambaran Pengetahuan Suami Dari Ibu Menyusui (0-6 bulan) Tentang ASI Eksklusif Di Wilayah Kerja Puskesmas Dermayu Kabupaten Seluma Tahun 2017. Journal Of Midwifery: 6(1).10-16.

Irwansyah Lubis. 2017. "Hubungan Karakteristik, Pengetahuan dan Sikap Ibu Dengan Pemberian ASI Eksklusif Di Wilayah Kerja Puskesmas Binjai Serbangan Kecamatan Air Joman Kabupaten Asahan Tahun 2017. Fakultas Kesehatan Masyarakat. Universitas Sumatera Utara.Medan.

Istiqomah dkk. 2015. Pengaruh Buah Pepaya Terhadap Kelancaran Produksi ASI Pada Ibu Menyusui Di Desa Wonokerto Wilayah Puskesmas Peterongan Jombang tahun 2014. Jurnal Edu Health: 5(2).102-108.

Listiyana Dewi Mukti Tri. 2017. Efektifitas Pendidikan Kesehatan Terhadap Pengetahuan Tentang Pemberian ASI Eksklusif Di Kelurahan Karangasem. Fakultas Ilmu Kesehatan. Universitas Muhammadiyah Surakarta. Surakarta.

Muhartono dkk. 2018. Pengaruh Pemberian Buah Pepaya (Carica Papaya L.) terhadap Kelancaran Produksi Air Susu Ibu (ASI) pada Ibu Menyusui. Medula: 8(2),39-42.

Rizki Natia Wiji. 2019. ASI dan Panduan Ibu Menyusui. Nuha Medika: Yogyakarta.

Soekidjo Notoatmodjo. 2012. Metodologi Penelitian Kesehatan. Rineka Cipta: Jakarta.

Sugiyono. 2018. Metode Penelitian Kuantitatif, Kualitatif, dan R\&D. ALFABETA: Bandung. 
Sulaiman, Anggriani. 2018. Efek Postur Tubuh Terhadap Keseimbangan lanjut Usia Di Desa Suka Raya Kecamatan Pancur. Jumantik (Jurnal Ilmiah Penelitian Kesehatan) 3 (2), 127-140. http://jurnal.uinsu.ac.id/index.php/kesmas/article/view/2875.

Taufan Nugroho. 2019. ASI dan Tumor Payudara. Nuha Medika: Yogyakarta.

Warjidin \& Rosmadewi. 2019. Efektifitas Sayur Pepaya Muda dan Sayur Daun Kelor terhadap Produksi ASI pada Ibu Post Partum Primipara. Jurnal Kesehatan: 10(1).84-92. http://ejurnal.poltekkes-tjk.ac.id/index.php/JK.

Weni Kristiyanasari. 2019. ASI, Menyusui \& Sadari. Nuha Medika: Yogyakarta. 